Review Article

\title{
Therapeutic Review on Nanocurcumin
}

\author{
K Lakshmi*, G Pazhani** \\ *Professor, ${ }^{* *}$ Associate Professor, Chettinad School of Pharmaceutical Sciences, Chettinad Academy of Research and Education, \\ Kelambakkam, Chennai, India
}

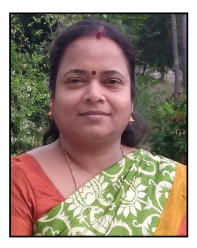

Dr. K. Lakshmi is currently working as Professor and Dean in-charge at Chettinad School of Pharmaceutical Sciences. She has completed her B.Pharm. and M.Pharm. from TN Dr. MGR Medical University and obtained her Ph.D. from SRM University. She has received travel grants from DST and AICTE. She has also received funded projects from DST and UGC. She has published many research articles in National and International Journals. Her field of research includes the quantitative estimation of drugs from formulations and biological samples using different analytical instruments like UV, HPLC and HPTLC.

Corresponding author - Dr. Lakshmi K. (laxmisiva@gmail.com)

Chettinad Health City Medical Journal 2020; 9(1): 53 - 58

DOI: https://doi.org/10.36503/chcmj9(1)-10

\begin{abstract}
An active natural polyphenol compound popularly known as curcumin has found its place in food, textile and pharmaceutical industry. Due to its wide spectrum of targets, curcumin-based researches are finding extensive application in the treatment of many diseases. Therapeutic application of curcumin finds its limitation due to its poor aqueous solubility. Researchers have exploited the application of nanomaterials to enhance the bioavailability of curcumin. Nanocurcumin are extensively studied due to their applications in specific target delivery. This review is an attempt to understand the therapeutic applications of nanocurcumin from recent publications.
\end{abstract}

Key words : Curcumin, nanocurcumin, nanoparticles, micelles, liposomes, solid lipid nanoparticles.

\section{Introduction}

An Important commercial spice grown in India belongs to the family of Zingiberaceae and is commonly known as Indian Saffron. Curcumin is a polyphenolic compound which is mainly extracted from this perennial herb Curcuma longa which belongs to the family Zingiberaceae. ${ }^{1}$ This has been used in siddha, unani and ayurvedic medicines due to its well documented health benefits. Chemically curcumin is known as (1E,6E)-1,7-bis (4-hydroxy-3methoxyphenyl)-1, 6-heptadiene-3,5-dione. It comprises of two aromatic ring systems containing o-methoxy phenolic group linked by a sevencarbon spacer consisting of an a,b unsaturated $b$ diketone moiety. Curcumin exhibits anticancer, antiviral, anti-oxidant, anti- inflammatory, hypoglycemic, antimicrobial, and antirheumatic properties. $^{2}$

Despite of several applications, curcumin usage as a therapeutic agent sets back because of poor solubility, poor absorption, rapid metabolism and rapid elimination. Many researchers have synthesized curcumin nanoparticles to overcome these obstacles and to improve the bioavailability. Nano curcumin was proven to possess better efficacy due to its better solubility and stability. The degradation of the loaded drug is protected in the nano size, thereby increasing the half-life. ${ }^{3}$

\section{Nano curcumin}

Novel curcumin nanoparticulated delivery approaches include polymeric nanoparticles, polymeric micelles, liposomes and solid lipid nanoparticles.

\section{Polymeric nanoparticles}

Biodegradability, biocompatibility and immunogenicity are the properties of biopolymers making them a versatile trait for in vitro and in vivo studies. Chitosan, carboxymethyl cellulose, poly lactic acid, poly hydroxy alkanoates, etc. are few widely used biopolymers in the drug delivery concepts. Among the different biopolymers, Chitosan based drug delivery are predominantly reported for the treatment of cancer, drug delivery to brain, pulmonary diseases, gastrointestinal diseases and in treating ocular infections (Table 1). Chitosan, a naturally occurring polysaccharide, is approved by US FDA and is the derivative of chitin, which is in turn obtained from crustacean shells of prawns or crabs. It is highly basic in nature and possesses good mucoadhesive properties. The permeation enhancing property of chitosan also facilitates the intracellular and paracellular transportation of loaded drugs. However, several factors like swelling index of the polymer, polymer degradation and diffusion property of the drug through polymer matrix governs the drug delivery at the targeted site..$^{4-12}$ 


\begin{tabular}{|c|c|c|c|}
\hline Sl. No. & Author name & Description & Therapeutic Activity \\
\hline 1 & $\begin{array}{l}\text { Rajesh } \\
\text { Sreedharan } \\
\text { Nair et al. }{ }^{4}\end{array}$ & $\begin{array}{l}\text { Curcumin loaded nanoparticle using chitosan } \\
\text { and sodium tripolyphosphate was reported. A } \\
\text { superior release and enhanced transdermal } \\
\text { permeation of curcumin was reported on } \\
\text { Strat-M membrane. }\end{array}$ & $\begin{array}{l}\text { An enhanced percentage cell } \\
\text { viability was reported as a result } \\
\text { of cy totoxic assay on human } \\
\text { keratinocyte cells. }\end{array}$ \\
\hline 2 & $\begin{array}{l}\text { Vinod } \\
\text { Vijayakurup } \\
\text { et al.5 }\end{array}$ & $\begin{array}{l}\text { Chitosan nanocurcumin ranging from size } 170 \\
\text { to } 200 \mathrm{~nm} \text { were reported. }\end{array}$ & $\begin{array}{l}\text { Cellular uptake and cytotoxicity in } \\
\text { lung cancer cells were reported. }\end{array}$ \\
\hline 3 & $\begin{array}{l}\text { Antony } \mathrm{V} \\
\text { Samrat et al. }\end{array}$ & $\begin{array}{l}\text { The demineralized extract of chitosan } \\
\text { obtained from Metacarcinus magister shells } \\
\text { was used. The curcumin loaded nanoparticles } \\
\text { was prepared using extracted chitosan and } \\
\text { sodium tripolyphosphate and barium chloride } \\
\text { as chelators. }\end{array}$ & $\begin{array}{l}\text { Antibacterial activity against } \\
\text { Pseudomonas aer uginosa and } \\
\text { Staphylococcus aureus were } \\
\text { studied }\end{array}$ \\
\hline 4 & $\begin{array}{l}\text { Khan MA et } \\
\text { al. }\end{array}$ & $\begin{array}{l}\text { Curcumin loaded chitosan nanoparticles with } \\
\text { sodium tripolyphosphate were prepared by } \\
\text { ionic gelation method. }\end{array}$ & $\begin{array}{l}\text { Increased uptake of curcumin was } \\
\text { reported on cervical cancer cell } \\
\text { lines like SiHa, CaSKi and HeLa. }\end{array}$ \\
\hline 5 & $\begin{array}{l}\text { Shruti } \\
\text { Maddrla et al. }\end{array}$ & $\begin{array}{l}\text { Different formulations using chitosan, } \\
\text { tripolyph osphate and Tween } 80 \text { were } \\
\text { prepared by ionic gelation method and } \\
\text { reported. }\end{array}$ & $\begin{array}{l}\text { Comparison of entrapment } \\
\text { efficiency and drug release } \\
\text { kinetics were reported. }\end{array}$ \\
\hline 6 & $\begin{array}{l}\text { Lilli Duse et } \\
\text { al.9}\end{array}$ & $\begin{array}{l}\text { Chitosan loaded curcumin nanoparticle with } \\
\text { good positive zeta potential was prepared. }\end{array}$ & $\begin{array}{l}\text { Upon irradiation using a novel LED } \\
\text { device }\left(\lambda_{\mathrm{ex}}=457 \mathrm{~nm}\right) \text {, curcumin } \\
\text { nanoparticles were able to } \\
\text { generate ROS and destroy tumor } \\
\text { cells. }\end{array}$ \\
\hline 7 & $\begin{array}{l}\text { Van Cuong } \\
\text { Nguyen et } a / .^{10}\end{array}$ & $\begin{array}{l}\text { Composite sponges using } 10 \% \text { curcumin, } \\
\text { chitosan and gelatin were prepared }\end{array}$ & $\begin{array}{l}\text { These composite sponges were } \\
\text { found to enhance the formation of } \\
\text { collagen and wound closure in vivo } \\
\text { and therefore improved the } \\
\text { wound healing activity }\end{array}$ \\
\hline 8 & $\begin{array}{l}\text { Thi Minh Phuc } \\
\text { Le et } a .^{11}\end{array}$ & $\begin{array}{l}\text { Curcumin-loaded NPs have been prepared by } \\
\text { an ionic gelation method using chitosan (Chi) } \\
\text { and pluronic R F - } 127 \text { (PF) as carriers to deliver } \\
\text { curcumin to the target cancer cells. }\end{array}$ & $\begin{array}{l}\text { Fluorescence Microscopy was } \\
\text { used to confirm the cellular } \\
\text { uptake of curcumin into HEK293 } \\
\text { cells }\end{array}$ \\
\hline 9 & $\begin{array}{l}\text { Lay Hon } \\
\text { Chuah et al.12 }\end{array}$ & $\begin{array}{l}\text { Curcumin loaded chitosan nanoparticles were } \\
\text { ionically gelled with tripolyphosphate were } \\
\text { prepared. }\end{array}$ & $\begin{array}{l}\text { Enhanced A dsorption isotherm of } \\
\text { mucin was observed on Freundlich } \\
\text { and Langmuir models. }\end{array}$ \\
\hline
\end{tabular}

\section{Polymeric Micelles}

Micelles are preferred mainly for targeting the delivery of hydrophobic drugs. Polymeric micelles prolong the circulation time of the nanoparticles in vivo thereby enhancing the cellular uptake, permeability and the retention effect. These properties are due to their composition as two layers namely inner core and outer shell. In addition to the precise delivery at the desired site, the double layer also protects the drug from $\mathrm{Gl}$ content and overcomes the degra- can be achieved by preparing mixed micelle using co-polymers (Table 2). ${ }^{13-18}$

\section{Liposomes}

Liposomes are characterized by their self-assembled spherical vesicles with one or more concentric phospholipid bilayers. Liposomes can encapsulate both hydrophilic and hydrophobic components with an order of aqueous inner layer and bilipid outer layer respectively. The lipid composition of the liposomes plays an important role in controlling the various factors like zeta potential, encapsulation cal stability and improved drug loading capacities 


\begin{tabular}{|c|c|c|c|}
\hline Sl. No. & Author name & Description & Therapeutic Activity \\
\hline 1 & Suping Ji et $a l^{13}$ & $\begin{array}{l}\text { A mixed micelle was developed with } \\
\text { Soluplus, an amphiphilic polyvinyl } \\
\text { caprolactampolyvinyl acetate-polyethylene } \\
\text { glycol graft copolymer and D- } \alpha \text {-tocopheryl } \\
\text { polyethylene glycol } 1000 \text { succinate (TPGS } \\
\text { 10oo) for curcumin delivery. Soluplus was } \\
\text { observed to improve the oral solubility of } \\
\text { poorly soluble drugs. TPGS } 1000 \text { was found } \\
\text { to enhance the drug entrapment efficiency, } \\
\text { drug solubility and stability properties. } \\
\text { Curcumin loaded soluplus mixed micelles } \\
\text { were prepared by modified film dispersion } \\
\text { method. }\end{array}$ & $\begin{array}{l}\text { Absorption of Soluplus micelles } \\
\text { were observed in the cytoplasm } \\
\text { region of MCF-7 cells. The lower cell } \\
\text { viability was observed and the } \\
\text { authors have expressed that these } \\
\text { micelles loaded with curcumin could } \\
\text { have a significant value for the } \\
\text { chronic breast cancer therapy. }\end{array}$ \\
\hline 2 & $\frac{\text { Woraphatphadung Tet }}{a I^{14}}$ & $\begin{array}{l}\text { The N-naphthyl-N,O-Succinyl chitosan and } \\
\mathrm{N} \text {-Octyl-N,O-Succinyl Chitosan polymeric } \\
\text { micelle carriers were prepared by physical } \\
\text { entrapment methods and were reported to } \\
\text { be pH sensitive. }\end{array}$ & $\begin{array}{l}\text { Anticancer activity against HT-29 } \\
\text { colorectal cancer cells was } \\
\text { reported. The release } \\
\text { characteristics was found to be pH } \\
\text { dependent and hence the name pH } \\
\text { sensitive. }\end{array}$ \\
\hline 3 & Fan Huang et $a l^{15}$ & $\begin{array}{l}\text { Silver nanoparticles were prepared and } \\
\text { decorating them in the micellar shell, which } \\
\text { in turn is absorbed by polyaspartic acid } \\
\text { chains in the shell. }\end{array}$ & $\begin{array}{l}\text { Antibacterial activity against } \\
\text { Pseudomonas aeruginosa and } \\
\text { S.aureus were reported. Good } \\
\text { biocompatibility and low hemolytic } \\
\text { activity were achieved using these } \\
\text { micelles. }\end{array}$ \\
\hline 4 & Kunquan Su et al. ${ }^{16}$ & $\begin{array}{l}\text { Polymeric micelles of curcumin that provide } \\
\text { sustained drug release were achieved by thin } \\
\text { film dispersion method using Pluronic P-123. }\end{array}$ & $\begin{array}{l}\text { The antitumor activity was assessed } \\
\text { in vitro by a ( } 3 \text { - }(4,5 \text {-dimethylthiazol- } \\
2 \text {-yl) -2,5-diphenyltetrazolium } \\
\text { bromide) assay on B16 cells. The } \\
\text { micelles showed sustained drug } \\
\text { release and excellent inhibitory } \\
\text { effect on tumor cells. }\end{array}$ \\
\hline 5 & $\begin{array}{l}\text { Ornchuma Naksuriya } \\
\text { et al. } .^{17}\end{array}$ & $\begin{array}{l}\text { Polymeric micelles were prepared by fast } \\
\text { heating method and nanoprecipitation } \\
\text { method. It comprises of block copolymers of } \\
\text { methoxypoly (ethylene glycol) (mPEG) } \\
\text { and } \mathrm{N} \text {-(2-hydroxypropyl) methacrylamide } \\
\text { (HPMA) modified with monolactate, dilactate } \\
\text { and benzoyl side groups to enhance the } \\
\text { solubility of curcumin. }\end{array}$ & $\begin{array}{l}\text { The prepared polymeric micelles } \\
\text { formulations were found to show a } \\
\text { significantly potent cytotoxic effect } \\
\text { against three different cancer cell } \\
\text { lines. }\end{array}$ \\
\hline 6 & Xi Yang et $a l^{18}$ & $\begin{array}{l}\text { Curcumin was encapsulated by single step } \\
\text { solid dispersion method into monomethyl } \\
\text { poly (ethylene glycol)-poly ( } \varepsilon \text {-caprolactone)- } \\
\text { poly (trimethylene carbonate) (MPEG-P(CL- } \\
\text { co-TMC)) micelles. }\end{array}$ & $\begin{array}{l}\text { The micelles could efficiently } \\
\text { suppress the growth of CT26 colon } \\
\text { carcinoma cells in vitro. They were } \\
\text { also found to be effective in } \\
\text { controlling the tumor growth of } \\
\text { subcutaneous CT26 colon in vivo. }\end{array}$ \\
\hline
\end{tabular}

efficiency, stability and release properties of drugs. The phospholipids, a main constituent of liposomes is found abundant in many tissues, it promotes the delivery of drugs to most of the targeted tissues (Table 3).19-24

\section{Solid Lipid Nanoparticles}

Solid Lipid nanoparticles are preferred for their excellent physical stability thereby protecting the drugs from chemical degradation. They offer few ideal properties like good physical and chemical stability, reasonably small particle size and an excellent biocompatibility. Wide range of both hydrophilic and hydrophobic compounds can be incorporated. The particle size of this category ranges from 120 -200 $\mathrm{nm}$ and hence provides an enhanced bioavailability and high reproducibility (Table 4 ). ${ }^{25-27}$ 


\begin{tabular}{|c|c|c|c|}
\hline SI. No. & Author name & Description & Therapeutic Activity \\
\hline 1 & $\begin{array}{l}\text { Bruna Sinjari et } \\
a / .^{19}\end{array}$ & $\begin{array}{l}\text { Curcumin loaded liposomes were } \\
\text { prepared using 1-palmitoyl } 2 \text { - } \\
\text { phosphatidylcholine }\end{array}$ & $\begin{array}{l}\text { Anti-inflammatory activities via } \\
\text { NFkB/ERK/pERK pathway in human } \\
\text { dental pulp treated with 2- Hydroxyethyl } \\
\text { Methacrylate (HEMA) }\end{array}$ \\
\hline 2 & $\mathrm{Ng} Z \mathrm{y}$ et $a l^{20}$ & $\begin{array}{l}\text { Curcumin and salbutamol liposomes were } \\
\text { formulated using lipid hydration method }\end{array}$ & $\begin{array}{l}\text { Prepared liposomes were tested on } \mathrm{BCl}- \\
\mathrm{NS} 1 \text { cell line to evaluate anti-inflammatory } \\
\text { property }\end{array}$ \\
\hline 3 & $\begin{array}{l}\text { Mahmoud Hasan } \\
\text { et al.:21 }\end{array}$ & $\begin{array}{l}\text { Salmon lecithin is used for the } \\
\text { preparation of curcumin loaded } \\
\text { liposomes. }\end{array}$ & $\begin{array}{l}\text { Application of nano liposomes in primary } \\
\text { cortical neurons demonstrated the } \\
\text { viability and formation of networks. The } \\
\text { decrease in apoptosis rate revealed the } \\
\text { neuroprotective role of the } \\
\text { nanoliposomes. }\end{array}$ \\
\hline 4 & Ce Cheng et $a l_{.22}^{22}$ & $\begin{array}{l}\text { Curcumin liposomes were prepared by a } \\
\mathrm{pH} \text { driven method that makes use of } \mathrm{pH}- \\
\text { dependent solubilization of curcumin and } \\
\text { the self-assembly behavior of } \\
\text { phospholipids in water. }\end{array}$ & $\begin{array}{l}\text { The } \mathrm{pH} \text { dependent preparation of } \\
\text { liposomes overcomes the use of organic } \\
\text { solvents when compared to other } \\
\text { techniques. }\end{array}$ \\
\hline 5 & $\begin{array}{l}\text { Geethi Pamunuwa } \\
\text { et al. }{ }^{23}\end{array}$ & $\begin{array}{l}\text { Positively charged and negatively charged } \\
\text { hybrid liposomes were prepared by thin } \\
\text { film hydration method using egg yolk } \\
\text { phosphatidylcholine. }\end{array}$ & $\begin{array}{l}\text { The charge of the liposomes was found to } \\
\text { have a significant effect on the skin } \\
\text { permeation property of curcumin. }\end{array}$ \\
\hline 6 & Yan Chen et al..24 & $\begin{array}{l}\text { Different kinds of curcumin loaded } \\
\text { liposomes were prepared using Soybean } \\
\text { phospholipids, egg yolk phospholipids, } \\
\text { and hydrogenated soybean phospholipids. }\end{array}$ & $\begin{array}{l}\text { In vitro skin permeation study and an } \\
\text { effect on antimelanoma activity on the } \\
\text { growth of B16BL } 6 \text { melanoma cells was } \\
\text { observed }\end{array}$ \\
\hline
\end{tabular}

Table 3: Therapeutic activity of curcumin loaded liposomes

\begin{tabular}{|l|l|l|l|}
\hline S.no & \multicolumn{1}{|c|}{ Author name } & \multicolumn{1}{|c|}{ Description } & \multicolumn{1}{c|}{ Therapeutic Activity } \\
\hline 1 & Bhatt $\mathrm{H}$ et al.25 & $\begin{array}{l}\text { Solid lipid nanoparticles were prepared } \\
\text { by using glyceryl monostearate in the } \\
\text { presence of a surfactant Poloxamer } 188 .\end{array}$ & $\begin{array}{l}\text { Higher apoptosis in MDA-MB } \\
\text { 231- breast adenocarcinoma } \\
\text { cells were reported }\end{array}$ \\
\hline 2 & Wenrui Wang et al.26 & $\begin{array}{l}\text { Curcumin solid lipid nanoparticles were } \\
\text { prepared by emulsification and low } \\
\text { temperature solidification method. }\end{array}$ & $\begin{array}{l}\text { Improved biological efficacy } \\
\text { against breast cancer } \\
\text { SKBR3cells in vitro was } \\
\text { reported }\end{array}$ \\
\hline 3 & Heba A et al. ${ }^{27}$ & $\begin{array}{l}\text { Curcumin solid lipid nanoparticles were } \\
\text { prepared and dispersed in a } \\
\text { mucoadhesive gel. }\end{array}$ & $\begin{array}{l}\text { Ex vivo muco adhesion and } \\
\text { permeation study was carried } \\
\text { out on chicken buccal mucosa. } \\
\text { An effective result was } \\
\text { obtained by the short-term } \\
\text { evaluation for the treatment } \\
\text { of oral precancerous lesions. }\end{array}$ \\
\hline \hline
\end{tabular}

Table 4: Therapeutic activity of curcumin loaded solid lipid nanoparticles

\section{Preparation techniques of Nanocurcu- mins}

Several methods are available for preparation of nanoparticles (Table 5). Selection of an appropriate method is important as it affects the particle size and the stability of the prepared nanoparticles. The physiochemical properties of the polymer and drug.

\section{Conclusion}

Curcumin, a natural antioxidant acts as a powerful bioactive agent. Reports on nanocurcumin reveal the increased solubility and bioavailability of curcumin. This short therapeutic review on recent publications reveals that the fabrication of curcumin as nano formulation could result in enhanced potency with optimal pharmacokinetic 


\begin{tabular}{|c|c|c|c|c|}
\hline S.no & Type & Structure & Particle Size & Methods of Preparation \\
\hline 1 & Polymeric nanoparticles ${ }^{28}$ & & $10-1000 \mathrm{~nm}$ & $\begin{array}{l}\text { Ionic Gelation } \\
\text { Nano precipitation } \\
\text { Emulsion cross linking method } \\
\text { Spray Drying } \\
\text { Salting Out method }\end{array}$ \\
\hline 2 & Polymeric Micelles ${ }^{29}$ & & $10-100 \mathrm{~nm}$ & $\begin{array}{l}\text { Direct dissolution } \\
\text { Dialysis Method } \\
\text { Emulsification method } \\
\text { Solvent Evaporation } \\
\text { Lyophilization or freeze drying }\end{array}$ \\
\hline 3 & Liposomes $^{30}$ & & $15-60 \mathrm{~nm}$ & $\begin{array}{l}\text { Solvent dispersion method } \\
\text { Detergent removal method } \\
\text { Mechanical dispersion method }\end{array}$ \\
\hline 4 & Solid Lipid Nanoparticles ${ }^{31}$ & lid) & $50-1000 \mathrm{~nm}$ & $\begin{array}{l}\text { Solvent emulsification - } \\
\text { evaporation } \\
\text { High pressure homogenization } \\
\text { Solvent emulsification-diffusion } \\
\text { Melting dispersion method } \\
\text { Double emulsion technique }\end{array}$ \\
\hline
\end{tabular}

Table 5: Commonly adopted methods of preparation techniques

properties. Nanocurcumin are referred as a potential therapeutic agent and finds extensive application in food and pharmaceutical industry.

\section{References}

1. Pandit RS, Gaikwad SC, Agarkar GA, Gade AK, Rai M. Curcumin nanoparticles: physico-chemical fabrication and its in vitro efficacy against human pathogens. 3 Biotech. 2015; 5: 991-7.

2. Rajasekhar PB, Bharani RSA, Angel KJ, Ramachandran M, Rajasekhar SPV. Curcumin nanoparticles: a therapeutic review. Research Journal of Pharmaceutical, Biological and Chemical Sciences. 2015; 6 (5): 1180-85.

3. Carvalho DD, Takeuchi KP, Geraldine RM, Moura CJ, Torres MC. Production, solubility and antioxidant activity of curcumin nanosuspension. Food Science and Technology. 2015; 35: 115-9.

4. Nair RS, Morris A, Billa N, Leong CO. An evaluation of curcumin-encapsulated chitosan nanoparticles for transdermal delivery. AAPS Pharm Sci Tech. 2019; 20: 69.

5. Vijayakurup V, Thulasidasan AT, Retnakumari AP, Nandan CD, Somaraj J, Antony J, Alex VV, Vinod BS, Liju VB, Sundaram S, Kumar GV. Chitosan encapsulation enhances the bioavailability and tissue retention of curcumin and improves its efficacy in preventing B [a] P-induced lung carcinogenesis. Cancer Prevention Research. 2019; 12: 225-36.

6. Samrot AV, Burman U, Philip SA, Shobana N, Chandrasekaran K. Synthesis of curcumin loaded polymeric nanoparticles from crab shell derived chitosan for drug delivery. Informatics in Medicine Unlocked. 2018; 10: 159-82.

7. Khan MA, Zafaryab M, Mehdi SH, Ahmad I, Rizvi M, Moshahid A. Physicochemical characterization of curcumin loaded chitosan nanoparticles: Implications in cervical cancer. Anti-Cancer Agents in Medicinal Chemistry (Formerly Current Medicinal Chemistry-Anti-Cancer Agents). 2018; 18: 1131-7.

8. Shruti Madderla, P. Tripura Sundari, Formulation and evaluation of curcumin loaded chitosan tripolyphosphate nanoparticles, International Education and Research Journal. 2018; 4: 6-9.

9. Duse L, Baghdan E, Pinnapireddy SR, Engelhardt KH, Jedelská J, Schaefer J, Quendt P, Bakowsky $U$. Preparation and characterization of curcumin loaded chitosan nanoparticles for photodynamic therapy. Physica Status Solidi (a). 2018; 215: 1700709. 
10. Nguyen VC, Nguyen VB, Hsieh MF. Curcumin-loaded chitosan/gelatin composite sponge for wound healing application. International Journal of Polymer Science. 2013; 2013: 106570.

11. Le TM, Dang TM, La TH, Le TH, Le QH. Preparation of curcumin-loaded pluronic F127/chitosan nanoparticles for cancer therapy. Advances in Natural Sciences: Nanoscience and Nanotechnology. 2013; 4: 025001.

12. Chuah LH, Billa N, Roberts CJ, Burley JC, Manickam S. Curcumin-containing chitosan nanoparticles as a potential mucoadhesive delivery system to the colon. Pharmaceutical development and technology. 2013; 18: 591-9.

13. Ji S, Lin X, Yu E, Dian C, Yan X, Li L, Zhang M, Zhao W, Dian L. Curcumin-loaded mixed micelles: Preparation, characterization, and in vitro antitumor activity. Journal of Nanotechnology. 2018; 2018: 9103120

14. Woraphatphadung T, Sajomsang W, Rojanarata T, Ngawhirunpat T, Tonglairoum P, Opanasopit P. Development of chitosan-based $\mathrm{pH}$-sensitive polymeric micelles containing curcumin for colon-targeted drug delivery. AAPS Pharm Sci Tech. 2018; 19: 991-1000.

15. Huang F, Gao Y, Zhang Y, Cheng T, Ou H, Yang L, Liu J, Shi L, Liu J. Silver-decorated polymeric micelles combined with curcumin for enhanced antibacterial activity. ACS applied materials \& interfaces. 2017; 9: 16880-9.

16. Su K, Yang Y, Wu Q, Mao Y, Hu Y. Preparation of Polymeric Micelles of Curcumin with Pluronic P123 and Assessment of Efficacy against B16 Cells In Vitro. Advances in Pharmacoepidemiology \& Drug Safety. 2016; 5: 1000202

17. Naksuriya O, Shi $Y$, Van Nostrum CF, Anuchapreeda S, Hennink WE, Okonogi S. HPMA-based polymeric micelles for curcumin solubilization and inhibition of cancer cell growth. European Journal of Pharmaceutics and Biopharmaceutics. 2015; 94: 501-12.

18. Yang X, Li Z, Wang N, Li L, Song L, He T, Sun L, Wang Z, Wu Q, Luo N, Yi C. Curcumin-encapsulated polymeric micelles suppress the development of colon cancer in vitro and in vivo. Scientific reports. 2015; 5: 10322.

19. Sinjari B, Pizzicannella J, D'Aurora M, Zappacosta R, Gatta V, Fontana A, Trubiani O, Diomede F. Curcumin/liposome nanotechnology as delivery platform for anti-inflammatory activities via NFkB/ERK/pERK pathway in human dental pulp treated with 2-hydroxyethyl methacrylate (HEMA). Frontiers in physiology. 2019;10: 633.

20. Ng ZY, Wong JY, Panneerselvam J, Madheswaran T, Kumar P, Pillay V, Hsu A, Hansbro N, Bebawy M, Wark P, Hansbro P. Assessing the potential of liposomes loaded with curcumin as a therapeutic intervention in asthma. Colloids and Surfaces B: Biointerfaces. 2018; 172: 51-9.

21. Hasan M, Latifi S, Kahn CJ, Tamayol A, Habibey R, Passeri E, Linder M, Arab-Tehrany E. The positive role of curcumin-loaded salmon nanoliposomes on the culture of primary cortical neurons. Marine drugs. 2018; 16: 218.

22. Cheng C, Peng S, Li Z, Zou L, Liu W, Liu C. Improved bioavailability of curcumin in liposomes prepared using a $\mathrm{pH}$-driven, organic solvent-free, easily scalable process. RSC advances. 2017; 7: 25978-86.

23. Pamunuwa G, Karunaratne V, Karunaratne D. Effect of lipid composition on in vitro release and skin deposition of curcumin encapsulated liposomes. Journal of Nanomaterials. 2016; 2016: 4535790

24. Chen Y, Wu Q, Zhang Z, Yuan L, Liu X, Zhou L. Preparation of curcumin-loaded liposomes and evaluation of their skin permeation and pharmacodynamics. Molecules. 2012; 17: 5972-87.

25. Bhatt H, Rompicharla SV, Komanduri N, Aashma S, Paradkar S, Ghosh B, Biswas S. Development of Curcumin-Loaded Solid Lipid Nanoparticles Utilizing Glyceryl Monostearate as Single Lipid Using QbD Approach: Characterization and Evaluation of Anticancer Activity Against Human Breast Cancer Cell Line. Current drug delivery. 2018; 15: 1271-83.

26. Wang W, Chen T, Xu H, Ren B, Cheng X, Qi R, Liu $\mathrm{H}$, Wang $\mathrm{Y}$, Yan L, Chen S, Yang $\mathrm{Q}$. Curcumin-loaded solid lipid nanoparticles enhanced anticancer efficiency in breast cancer. Molecules. 2018; 23: 1578.

27. Hazzah HA, Farid RM, Nasra MM, Zakaria M, Gawish Y, El-Massik MA, Abdallah OY. A new approach for treatment of precancerous lesions with curcumin solid-lipid nanoparticle-loaded gels: in vitro and clinical evaluation. Drug delivery. 2016; 23: 1409-19.

28. Jawahar N, Meyyanathan SN. Polymeric nanoparticles for drug delivery and targeting: A comprehensive review. International Journal of Health \& Allied Sciences. 2012; 1: 217.

29. Cholkar K, Patel A, Dutt Vadlapudi A, K Mitra A. Novel nanomicellar formulation approaches for anterior and posterior segment ocular drug delivery. Recent patents on nanomedicine. 2012; 2: 82-95.

30. Akbarzadeh A, Rezaei-Sadabady R, Davaran S, Joo SW, Zarghami N, Hanifehpour Y, Samiei M, Kouhi M, Nejati-Koshki K. Liposome: classification, preparation, and applications. Nanoscale research letters. 2013; 8: 102.

31. Ram DT, Debnath S, Babu MN, Nath TC, Thejeswi B. A review on solid lipid nanoparticles. Research Journal of Pharmacy and Technology. 2012; 5: 1359-68. 